\title{
Social Communication and Language Deficits in Parents and Siblings of Children with ASD - A Short Review
}

\author{
Ewa Pisula and Karolina Ziegart-Sadowska \\ Additional information is available at the end of the chapter \\ http://dx.doi.org/10.5772/59134
}

\section{Introduction}

Autism spectrum disorders (ASD) are a group of neurodevelopmental disorders associated with severe deficits in social communication, often accompanied by restricted patterns of behaviour, activity and interests [1]. ASD prevalence has been on the rise and is currently estimated to be 1:68 with higher rates for boys (1:42) than girls (1:189) [2].

Social, communication and cognitive deficits typical for ASD can affect individual sufferers with various severity and in many different combinations, which prompted the concept of autistic continuum, later replaced by autistic spectrum [3,4] Already in the earliest publications on autism, Kanner [5] and Asperger [6] identified certain similarities in the untypical severity of certain traits and behaviours in children with autism and their parents, such as tendency to social withdrawal, limited interest in people, late speech development and pedantry. Further research demonstrated that autistic traits are more prevalent in the closest relatives of individuals with ASD than in other groups [7-11].

Subtle, subclinical traits or characteristics that parallel the defining features of autism, present in non-affected individuals, in particular the first-degree relatives of people with autism, are referred to as "Broader Autism Phenotype" (BAP) [10-13]. The presence of specific characteristics in terms of social and communication skills, cognitive processes and personality in parents and siblings of individuals with ASD may suggest genetic involvement in the aetiology of autism, what is strongly supported by evidence obtained from twin and family studies. Research in this area may expand our knowledge of the nature of autism and the mechanisms underlying the emergence of its characteristic symptoms [14].

It has been estimated that BAP characteristics may be presented in at least $10-20 \%$ of parents and siblings of children with these disorders [12, 15]. For instance, Bolton et al. [12] found out 
that $12,4 \%$ of siblings of the autistic probants compared to only $1,6 \%$ of the siblings of Down's syndrome were described as performing autistic traits, but of a less severe degree. In spite of many studies considering difficulties demonstrated by relatives of children with ASD, specific determination of characteristics included in BAP requires further research.

A number of publications have described the specific personality traits of parents and siblings of children with ASD: shyness, preference to be alone, insistence on sameness, reluctance to change and obsessive-compulsive behaviours $[16,17]$. There are also data on the mental health problems in members of these families [18], although the results of studies in this area are not consistent (see: [19] for review).

In addition, the relatives of children with ASD demonstrate a specific cognitive characteristics. They achieved lower scores in attribution mental states based on facial expressions tasks [20], showed weaker central coherence (e.g. [16, 20, 21]), and a lower level of efficiency in planning, attention shifting and other executive function [22-26].

Several comprehensive reviews of the few dozen years of research on BAP have been published (e.g. $[7,14,27,28])$. In this article we will be focusing on social communication problems such as understanding body language and emotional expression, as well as specific language characteristics in parents and siblings of people with ASD. Impaired language and social communication problems are defining elements of autism and include a delay or lack of spoken language that cannot be compensated by other means of communication, difficulties in initiation and maintenance of conversation as well as repetitive and stereotypic language patterns and expressions [29]. The deficits in these domains are recognized as the key features of broader autism phenotype [13, 30, 31].

This review was conducted in the first half of 2014 using the following electronic databases of international literature: Web of Science, MEDLINE/PubMed, SCOPUS, EBSCO. The articles reviewed were published from 1992 to May 2014. Keywords related to phenotype, endophenotype, autism, parents, siblings and family were used. The next step was to select studies meeting the following criteria: a) published in English; b) the social communication and language characteristics of autism in parents and siblings of individuals with autism were objects of study; c) original studies. We have excluded articles that did not explore the themes of social communication and language, those that discussed research on BAP in general population or more distant relatives of individuals with ASD rather than in their parents and siblings, as well as studies that did not include a control group.

\section{Research on social communication and language in parents and siblings of individuals with ASD}

Tab. 1 presents a summary of information about research on social communication and language in parents and siblings of individuals with autism. Descriptions of individual studies are limited to themes associated with social communication and language, although the majority of reviewed articles covered other aspects of BAP as well. 


\begin{tabular}{|c|c|c|c|}
\hline Study & Characteristics & Participants & Main results \\
\hline $\begin{array}{l}\text { Landa et al. (1992) } \\
\text { [32] }\end{array}$ & $\begin{array}{l}\text { Pragmatic language; } \\
\text { verbal interactions }\end{array}$ & $\begin{array}{l}43 \text { ASD parents (sex } \\
\text { ratio not reported); } \\
21 \text { control adults (sex } \\
\text { ratio not reported) }\end{array}$ & $\begin{array}{l}42 \% \text { of ASD parents had some pragmatic } \\
\text { language deficit, compared to } 2 \% \text { of controls }\end{array}$ \\
\hline $\begin{array}{l}\text { Szatmari et al. } \\
\text { (1993) [33] }\end{array}$ & $\begin{array}{l}\text { Cognitive } \\
\text { impairments } \\
\text { including language; } \\
\text { developmental history }\end{array}$ & $\begin{array}{l}\text { The unaffected siblings and } \\
\text { parents of } 52 \text { PDD probands and } \\
33 \text { Down syndrome and low } \\
\text { birth weight controls }\end{array}$ & $\begin{array}{l}\text { No differences on the social and communication } \\
\text { domains of the Vineland Adaptive Behavior } \\
\text { Scales in ASD siblings compared to control } \\
\text { siblings; } \\
\text { No group differences in developmental history } \\
\text { of language delays }\end{array}$ \\
\hline $\begin{array}{l}\text { Bolton et al. (1994) } \\
\text { [12] }\end{array}$ & $\begin{array}{l}\text { Social and } \\
\text { communication } \\
\text { impairments }\end{array}$ & $\begin{array}{l}\text { ASD relatives (198 parents, } 137 \\
\text { siblings); } \\
\text { Control relatives ( } 72 \text { parents, } 64 \\
\text { siblings) }\end{array}$ & $\begin{array}{l}20.4 \% \text { of ASD siblings (and } 3.1 \% \text { of control } \\
\text { siblings) showed communication atypicalities, } \\
\text { social impairments, or restricted behaviors; } \\
\text { The same pattern of results in parents, but to a } \\
\text { lesser degree }\end{array}$ \\
\hline $\begin{array}{l}\text { Baron-Cohen and } \\
\text { Hammer (1997) } \\
\text { [34] }\end{array}$ & $\begin{array}{l}\text { Reading emotions in } \\
\text { the eyes }\end{array}$ & $\begin{array}{l}30 \text { ASD parents ( } 15 \text { mothers and } \\
15 \text { fathers); } 30 \text { control adults ( } 15 \\
\text { females and } 15 \text { males) }\end{array}$ & $\begin{array}{l}\text { Parents of children with autism were slighly } \\
\text { impaired in emotion recognition }\end{array}$ \\
\hline $\begin{array}{l}\text { Fombonne et al. } \\
\text { (1997) [35] }\end{array}$ & $\begin{array}{l}\text { Verbal intelligence, } \\
\text { reading and spelling } \\
\text { skills }\end{array}$ & $\begin{array}{l}99 \text { first-degree ASD relatives; } 36 \\
\text { relatives of individuals with } \\
\text { Down syndrome }\end{array}$ & $\begin{array}{l}\text { Slightly higher mean verbal IQ scores in relatives } \\
\text { of ASD individuals; } \\
\text { Siblings of ASD individuals, affected with the } \\
\text { broad phenotype of autism, had significantly } \\
\text { lower IQ scores, poorer reading and spelling } \\
\text { abilities than unaffected siblings }\end{array}$ \\
\hline $\begin{array}{l}\text { Piven and Palmer } \\
\text { (1997) [25] }\end{array}$ & $\begin{array}{l}\text { Reading and spelling } \\
\text { performance }\end{array}$ & $\begin{array}{l}25 \text { mothers and } 23 \text { fathers from } \\
25 \text { multiple-incidence autism } \\
\text { families; } 30 \text { mothers and } 30 \\
\text { fathers from } 30 \text { Down } \\
\text { syndrome families }\end{array}$ & $\begin{array}{l}\text { ASD parents showed weaker reading } \\
\text { performance (passage comprehension and rapid } \\
\text { automatized naming) compared to parents of } \\
\text { individuals with DS }\end{array}$ \\
\hline $\begin{array}{l}\text { Piven, Palmer, } \\
\text { Landa, } \\
\text { Santangelo, Jacobi, } \\
\text { Childress (1997) } \\
\text { [10] }\end{array}$ & Pragmatic language & $\begin{array}{l}39 \text { multiple-incidence autism } \\
\text { parents (having two children } \\
\text { with autism); } 58 \text { parents of } \\
\text { children with Down syndrome }\end{array}$ & $\begin{array}{l}\text { Higher rates of speech and pragmatic language } \\
\text { deficits in multiple-incidence autism parents }\end{array}$ \\
\hline $\begin{array}{l}\text { Piven, Palmer, } \\
\text { Jacobi, Childress } \\
\text { and Arndt (1997) } \\
\text { [11] }\end{array}$ & $\begin{array}{l}\text { Social and } \\
\text { communication } \\
\text { deficits }\end{array}$ & $\begin{array}{l}25 \text { multiplex autism families; } \\
\text { relatives of } 30 \text { Down syndrome } \\
\text { probands }\end{array}$ & $\begin{array}{l}\text { Higher rates of social and communication } \\
\text { deficits in the families with multiple-incidence } \\
\text { autism }\end{array}$ \\
\hline $\begin{array}{l}\text { Folstein et al. } \\
\text { (1999) [36] }\end{array}$ & $\begin{array}{l}\text { Pragmatic language; } \\
\text { verbal IQ; reading and } \\
\text { spelling performance }\end{array}$ & $\begin{array}{l}166 \text { parents and } 87 \text { siblings of } \\
\text { individuals with autism; } 75 \\
\text { parents and } 64 \text { siblings of } \\
\text { children with Down syndrome }\end{array}$ & $\begin{array}{l}\text { No differences in verbal IQ scores, reading and } \\
\text { spelling skills; More deficits in pragmatic } \\
\text { language in parents of individuals with autism }\end{array}$ \\
\hline
\end{tabular}




\begin{tabular}{|c|c|c|c|}
\hline Study & Characteristics & Participants & Main results \\
\hline & & & $\begin{array}{l}\text { as well as early language-related difficulties in } \\
\text { that group }\end{array}$ \\
\hline $\begin{array}{l}\text { Hughes et al. } \\
\text { (1999) [22] }\end{array}$ & Verbal fluency & $\begin{array}{l}31 \text { siblings of children with } \\
\text { autism; } 32 \text { siblings of children } \\
\text { with developmental delay }\end{array}$ & $\begin{array}{l}\text { Superior verbal span in siblings of children with } \\
\text { autism; Bigger than expected part of that group } \\
\text { of siblings achieved poor results in verbal } \\
\text { fluency tasks }\end{array}$ \\
\hline $\begin{array}{l}\text { Pilowsky et al. } \\
\text { (2003) [37] }\end{array}$ & Language abilities & $\begin{array}{l}27 \text { siblings of children with } \\
\text { autism, } 23 \text { siblings of children } \\
\text { with mental retardation of } \\
\text { unknown etiology, } 22 \text { siblings of } \\
\text { children with developmental } \\
\text { language disorders }\end{array}$ & $\begin{array}{l}\text { Higher scores in siblings of children with autism } \\
\text { on receptive, expressive, and total language } \\
\text { scales of the Children's Evaluation of Language } \\
\text { Fundamentals and on verbal IQ compared to } \\
\text { siblings of children with developmental } \\
\text { language disorders }\end{array}$ \\
\hline Bishop (2004) [8] & $\begin{array}{l}\text { Communication skills } \\
\text { (self-report measure) }\end{array}$ & $\begin{array}{l}\text { Children with ASD (59 with } \\
\text { autism, } 21 \text { with PDD-NOS); } \\
\text { ASD parents ( } 65 \text { mothers, } 46 \\
\text { fathers); } \\
\text { Control parents ( } 48 \text { mothers, } 37 \\
\text { fathers) }\end{array}$ & $\begin{array}{l}\text { Communication skills } \\
\text { significantly lower in ASD parents (particularly } \\
\text { fathers) compared to control parents }\end{array}$ \\
\hline $\begin{array}{l}\text { Bishop et al. } \\
\text { (2004b) [38] }\end{array}$ & $\begin{array}{l}\text { Phonological } \\
\text { processing, } \\
\text { communication }\end{array}$ & $\begin{array}{l}145 \text { parents of children with } \\
\text { ASD; } \\
96 \text { parents of typically } \\
\text { developing children }\end{array}$ & $\begin{array}{l}\text { No difference in phonological processing; } \\
\text { In the group of parents classified as BAP there } \\
\text { was a history of more language and literacy } \\
\text { problems than in other ASD parents }\end{array}$ \\
\hline $\begin{array}{l}\text { Dorris et al. } \\
\text { (2004) [39] }\end{array}$ & $\begin{array}{l}\text { Mind-reading (Eyes } \\
\text { Test) }\end{array}$ & $\begin{array}{l}27 \text { siblings of children with } \\
\text { Asperger syndrome (AS); } \\
27 \text { control children }\end{array}$ & $\begin{array}{l}\text { Poorer performance of the AS siblings in the Eyes } \\
\text { Test }\end{array}$ \\
\hline $\begin{array}{l}\text { Hill, Berthoz and } \\
\text { Frith (2004) [40] }\end{array}$ & Emotion processing & $\begin{array}{l}27 \text { high-functioning adults with } \\
\text { autistic spectrum disorders, their } \\
\text { biological relatives ( } n=49) \text {, and } \\
\text { normal adult controls }(n=35)\end{array}$ & $\begin{array}{l}\text { No significant differences between relatives of } \\
\text { individuals with ASD and controls in identifying } \\
\text { and describing feelings }\end{array}$ \\
\hline Bishop (2006) [41] & $\begin{array}{l}\text { Communication } \\
\text { deficits (assessed by } \\
\text { parents using } \\
\text { Children's } \\
\text { Communication } \\
\text { Checklist-2, CCC-2) }\end{array}$ & $\begin{array}{l}43 \text { ASD siblings; } \\
46 \text { control children }\end{array}$ & $\begin{array}{l}\text { The only difference between groups in syntax; } \\
23.8 \% \text { of ASD siblings scored } 2 \text { SD below the } \\
\text { control mean on CCC-2, compared to } 2.2 \% \text { of } \\
\text { controls; } \\
\text { Some differences in structural } \\
\text { language skills }\end{array}$ \\
\hline $\begin{array}{l}\text { Palermo et al. } \\
\text { (2006) [42] }\end{array}$ & $\begin{array}{l}\text { Recognition of } \\
\text { schematic displayed } \\
\text { emotions }\end{array}$ & $\begin{array}{l}40 \text { parents of children with } \\
\text { autism, } 40 \text { control adults }\end{array}$ & $\begin{array}{l}\text { Poorer performance in parents of children with } \\
\text { autism; Fathers of children with autism had more } \\
\text { difficulties than mothers }\end{array}$ \\
\hline $\begin{array}{l}\text { Chuthapisith et al. } \\
\text { (2007) [43] }\end{array}$ & $\begin{array}{l}\text { Language } \\
\text { development }\end{array}$ & $\begin{array}{l}32 \text { preschool siblings of children } \\
\text { with autism (aged 2-6 years); } 28 \\
\text { control children }\end{array}$ & $\begin{array}{l}\text { Delayed language development in } 8 \text { of autism } \\
\text { siblings; After excluded the siblings with ASD } \\
\text { and DLD diagnosis, in the remaining } 29 \text { siblings }\end{array}$ \\
\hline
\end{tabular}




\begin{tabular}{|c|c|c|c|}
\hline Study & Characteristics & Participants & Main results \\
\hline & & & $\begin{array}{l}\text { verbal IQs were not significantly different from } \\
\text { the control group }\end{array}$ \\
\hline $\begin{array}{l}\text { Di Michele et al. } \\
\text { (2007) [44] }\end{array}$ & $\begin{array}{l}\text { Pragmatic language } \\
\text { (evaluation of the } \\
\text { taped conversations) }\end{array}$ & $\begin{array}{l}23 \text { parents of children with } \\
\text { autism; } 12 \text { parents of children } \\
\text { with Down syndrome and } 23 \\
\text { parents of healthy children }\end{array}$ & $\begin{array}{l}\text { More pragmatic language difficulties in parents } \\
\text { of people with autism; } \\
\text { Problems in identifying relevant and redundant, } \\
\text { non-essential information }\end{array}$ \\
\hline $\begin{array}{l}\text { Losh and Piven } \\
\text { (2007) [45] }\end{array}$ & $\begin{array}{l}\text { Ability to read } \\
\text { complex psychological } \\
\text { states from viewing } \\
\text { only the eye region of } \\
\text { faces }\end{array}$ & $\begin{array}{l}48 \text { parents of individuals with } \\
\text { autism; } 22 \text { control parents, } \\
\text { including parents of individuals } \\
\text { with Down syndrome and } \\
\text { typically developing children }\end{array}$ & $\begin{array}{l}\text { No differences between parents of individuals } \\
\text { with autism and Controls; } \\
\text { There was an ,aloof" subgroup identified among } \\
\text { parents of individuals with autism }(\mathrm{n}=13) \text {; The } \\
\text { results of that group were lower than the results } \\
\text { obtained by Controls in the Eyes Test }\end{array}$ \\
\hline $\begin{array}{l}\text { Ruser et al. (2007) } \\
\text { [46] }\end{array}$ & $\begin{array}{l}\text { Communicative } \\
\text { competence; } \\
\text { pragmatic language, } \\
\text { over-talkativeness }\end{array}$ & $\begin{array}{l}47 \text { parents of individuals with } \\
\text { autism; } 47 \text { parents of children } \\
\text { with specific language } \\
\text { impairment (SLI); } 21 \text { parents of } \\
\text { children with Down syndrome }\end{array}$ & $\begin{array}{l}\text { Parents of children with autism and SLI } \\
\text { presented lower communication abilities than } \\
\text { parents of children with DS; } \\
\text { Severe pragmatic language deficits in about 15\% } \\
\text { of autism and SLI parents }\end{array}$ \\
\hline $\begin{array}{l}\text { Pilowsky et al. } \\
\text { (2007) [47] }\end{array}$ & $\begin{array}{l}\text { Neurocognitive } \\
\text { functioning }\end{array}$ & $\begin{array}{l}30 \text { siblings of children with } \\
\text { autism; } 28 \text { siblings of children } \\
\text { with mental retardation, } 30 \\
\text { siblings of children with } \\
\text { developmental language delay }\end{array}$ & $\begin{array}{l}\text { No differences between siblings of children with } \\
\text { autism and the other groups }\end{array}$ \\
\hline $\begin{array}{l}\text { Whitehouse et al. } \\
\text { (2007) [48] }\end{array}$ & $\begin{array}{l}\text { Communication (self } \\
\text { report measure: } \\
\text { Autism Quotient by } \\
\text { Baron-Cohen et al., } \\
2001 \text { ) }\end{array}$ & $\begin{array}{l}30 \text { parents of children with } \\
\text { autism; } 30 \text { parents of children } \\
\text { with specific language } \\
\text { impairment; } 30 \text { parents of } \\
\text { children typically developing }\end{array}$ & $\begin{array}{l}\text { Communication difficulties in parents of children } \\
\text { with autism }\end{array}$ \\
\hline $\begin{array}{l}\text { Adolphs et al. } \\
\text { (2008) [49] }\end{array}$ & Face processing & $\begin{array}{l}15 \text { socially 'aloof' parents of } \\
\text { individuals with autism; } 27 \\
\text { 'nonaloof' parents of children } \\
\text { with autism; } 20 \text { control parents of } \\
\text { neurotypical children }\end{array}$ & $\begin{array}{l}\text { Socially 'aloof' parents showed poorer } \\
\text { performance compared to 'nonaloof' parents and } \\
\text { control parents } \\
\end{array}$ \\
\hline $\begin{array}{l}\text { Scheeren and } \\
\text { Stauder (2008) [50] }\end{array}$ & $\begin{array}{l}\text { Communication } \\
\text { (measured by AQ) }\end{array}$ & $\begin{array}{l}25 \text { parents of children with HFA; } \\
25 \text { parents of typically } \\
\text { developing children }\end{array}$ & No differences between groups \\
\hline $\begin{array}{l}\text { Schmidt et al. } \\
\text { (2008) [51] }\end{array}$ & $\begin{array}{l}\text { Phonological } \\
\text { processing }\end{array}$ & $\begin{array}{l}22 \text { parents of children with } \\
\text { autism; } 22 \text { controls }\end{array}$ & $\begin{array}{l}\text { ASD parents achieved lower scores on the } \\
\text { nonword repetition task; No differences between } \\
\text { groups in figurative language, receptive } \\
\text { language, expressive language, verbal fluency } \\
\text { and in history of reading difficulties }\end{array}$ \\
\hline $\begin{array}{l}\text { Losh et al. (2008) } \\
{[13]}\end{array}$ & Pragmatic language & $\begin{array}{l}48 \text { parents of individuals with } \\
\text { autism (multiple-incidence }\end{array}$ & $\begin{array}{l}\text { More pragmatic and speech errors in MIAF } \\
\text { parents than in SIAF parents; SIAF parents }\end{array}$ \\
\hline
\end{tabular}




\begin{tabular}{|c|c|c|c|}
\hline Study & Characteristics & Participants & Main results \\
\hline & & $\begin{array}{l}\text { autism families - MIAF); } 78 \\
\text { parents of individuals with } \\
\text { autism (single-incidence autism } \\
\text { families - SIAF); } 60 \text { parents of } \\
\text { individuals with Down } \\
\text { syndrome }\end{array}$ & $\begin{array}{l}\text { committed significantly more pragmatic } \\
\text { violations and speech errors than Down } \\
\text { syndrome parents }\end{array}$ \\
\hline $\begin{array}{l}\text { Gamliel et al. } \\
\text { (2009) [52] }\end{array}$ & $\begin{array}{l}\text { Language } \\
\text { development }\end{array}$ & $\begin{array}{l}37 \text { siblings of children with ASD } \\
\text { (SIBS-A); } 47 \text { siblings of typically } \\
\text { developing children (SIBS-TD) } \\
\text { (longitudinal study: from } 4 \\
\text { months to } 7 \text { years) }\end{array}$ & $\begin{array}{l}\text { At } 7 \text { years, } 40 \% \text { of the SIBS-A } \\
\text { (and } 16 \% \text { of SIBS-TD) showed cognitive, } \\
\text { language and/or academic difficulties (this sub- } \\
\text { group was named SIBS-A-BP); Early language } \\
\text { scores (14-54 months) were significantly lower in } \\
\text { SIBS-A-BP compared to the language scores of } \\
\text { SIBS-TD. Language was a major area of difficulty } \\
\text { for SIBS-A during the preschool years }\end{array}$ \\
\hline $\begin{array}{l}\text { Lindgren et al. } \\
\text { (2009) [53] }\end{array}$ & $\begin{array}{l}\text { Syntax memory for } \\
\text { language, Lexical } \\
\text { comprehension, } \\
\text { Semantics, } \\
\text { Morphology, Reading } \\
\text { abilities }\end{array}$ & $\begin{array}{l}62 \text { parents of children with } \\
\text { autism and language } \\
\text { impairment; } 39 \text { parents of } \\
\text { children without autism and } \\
\text { language impairment; } 70 \text { parents } \\
\text { of children with specific } \\
\text { language impairment }\end{array}$ & $\begin{array}{l}\text { Parents of people with autism and language } \\
\text { impairment had a better performance in } \\
\text { language tests than parents of children with } \\
\text { specific language impairment }\end{array}$ \\
\hline $\begin{array}{l}\text { Losh et al. (2009) } \\
\text { [54] }\end{array}$ & $\begin{array}{l}\text { Reading complex } \\
\text { psychological states } \\
\text { from the eye region of } \\
\text { faces }\end{array}$ & $\begin{array}{l}36 \text { high-functioning individuals } \\
\text { with autism, } 41 \text { controls } \\
\text { (neurotypical individuals with } \\
\text { no family history of autism), } 83 \\
\text { parents of individuals with } \\
\text { autism, } 32 \text { control parents (with } \\
\text { no family history of autism or } \\
\text { developmental delays) }\end{array}$ & $\begin{array}{l}\text { There were three groups of parents of } \\
\text { individuals with autism extracted: group of } \\
\text { parents with social BAP characteristics ( } \mathrm{n}=22) \text {; } \\
\text { group with the rigid/perfectionistic BAP traits ( } \mathrm{n} \\
=34 \text { ), and group without BAP features BAP (-) ( } \mathrm{n} \\
=40 \text { ). } \\
\text { In Reading the Mind in the Eyes Test parents of } \\
\text { individuals with autism with social BAP } \\
\text { performed poorer than control parents. No } \\
\text { difference between Controls and BAP (-) parents }\end{array}$ \\
\hline $\begin{array}{l}\text { Ben-Yizhak et al. } \\
\text { (2011) [55] }\end{array}$ & $\begin{array}{l}\text { Pragmatic language, } \\
\text { school related } \\
\text { linguistic abilities }\end{array}$ & $\begin{array}{l}\text { School-age siblings of children } \\
\text { with autism (SIBS-A), } \mathrm{n}=35 \text {; } \\
\text { Controls }(\mathrm{n}=42)\end{array}$ & $\begin{array}{l}\text { Lower pragmatic abilities in a subgroup of SIBS- } \\
\text { A identified with BAP related difficulties; No } \\
\text { differences between groups in school } \\
\text { achievements and reading processes }\end{array}$ \\
\hline $\begin{array}{l}\text { Losh et al. (2010) } \\
\text { [23] }\end{array}$ & $\begin{array}{l}\text { Rapid automatized } \\
\text { naming }\end{array}$ & $\begin{array}{l}\text { Three samples: } \\
\text { I: } 48 \text { parents of multiple children } \\
\text { with ASD; } 62 \text { parents with a } \\
\text { single child with autism; } 53 \\
\text { parents of children with Down } \\
\text { syndrome; }\end{array}$ & $\begin{array}{l}\text { Longer naming times in parents of individuals } \\
\text { with autism and in people with HFA compared } \\
\text { to controls }\end{array}$ \\
\hline
\end{tabular}




\begin{tabular}{|c|c|c|c|}
\hline Study & Characteristics & Participants & Main results \\
\hline & & $\begin{array}{l}\text { II: } 167 \text { parents from multiplex } \\
\text { families; } \\
\text { III: } 83 \text { parents of individuals with } \\
\text { autism, } 32 \text { parent controls, } 36 \\
\text { high-functioning individuals } \\
\text { with autism, } 38 \text { controls }\end{array}$ & \\
\hline $\begin{array}{l}\text { Wheelwright et al. } \\
\text { (2010) [56] }\end{array}$ & $\begin{array}{l}\text { Communication (self- } \\
\text { report using AQ) }\end{array}$ & $\begin{array}{l}\text { 2,000 parents of children with } \\
\text { ASD ( } 571 \text { fathers and } 1429 \\
\text { mothers); 1,007 parents of } \\
\text { typically developing children } \\
\text { (349 fathers and } 658 \text { mothers) }\end{array}$ & $\begin{array}{l}\text { Parents of children with ASD showed more } \\
\text { communication difficulties }\end{array}$ \\
\hline $\begin{array}{l}\text { Whitehouse et al. } \\
\text { (2010) [57] }\end{array}$ & $\begin{array}{l}\text { Language (speech, } \\
\text { syntax and semantics), } \\
\text { pragmatic skills, } \\
\text { communication style }\end{array}$ & $\begin{array}{l}238 \text { parents of children with } \\
\text { autism; } 187 \text { parents of typical } \\
\text { individuals }\end{array}$ & $\begin{array}{l}\text { No differences between groups in the language } \\
\text { subscale }\end{array}$ \\
\hline $\begin{array}{l}\text { Levy and Bar- } \\
\text { Yuda (2011) [58] }\end{array}$ & $\begin{array}{l}\text { Language } \\
\text { performance }\end{array}$ & $\begin{array}{l}\text { Siblings of nonverbal children } \\
\text { with autism SIBS-ANV }(\mathrm{n}=28) \text {; } \\
\text { Controls ( } \mathrm{n}=27) \text {; aged } 4-9 \text { years }\end{array}$ & $\begin{array}{l}\text { SIBS-ANV achieved lower scores on the } \\
\text { Receptive Scale, Expressive Scale and the Total } \\
\text { Language Scale of the Clinical Evaluation of } \\
\text { Language Fundamentals; Differences in the } \\
\text { language scores were associated with IQ }\end{array}$ \\
\hline $\begin{array}{l}\text { Neves et al. (2011) } \\
\text { [59] }\end{array}$ & $\begin{array}{l}\text { Facial emotion } \\
\text { recognition }\end{array}$ & $\begin{array}{l}40 \text { parents of children with } \\
\text { autism; } 41 \text { healthy controls }\end{array}$ & $\begin{array}{l}\text { Parents of children with autism performed worse } \\
\text { in the facial emotion recognition test than } \\
\text { controls }\end{array}$ \\
\hline $\begin{array}{l}\text { Bernier et al. } \\
\text { (2012) [60] }\end{array}$ & Conversational skills & $\begin{array}{l}39 \text { parents of multiple-incidence } \\
\text { autism families (M-parents); } 22 \\
\text { parents of single-incidence } \\
\text { autism families (S-parents); } 20 \\
\text { parents of children with } \\
\text { developmental delay without } \\
\text { ASD (DD); } 20 \text { parents of } \\
\text { typically-developing children }\end{array}$ & $\begin{array}{l}\text { Greater impairment in social communication } \\
\text { skills in M-parents compared with S-parents, DD } \\
\text { parents, and parents of typically developing } \\
\text { children }\end{array}$ \\
\hline $\begin{array}{l}\text { Berthoz et al. } \\
\text { (2013) [61] }\end{array}$ & $\begin{array}{l}\text { Emotional } \\
\text { impairments }\end{array}$ & $\begin{array}{l}\text { High functioning adults with } \\
\text { ASD }(n=38) \text {, parents of } \\
\text { individuals with ASD }(n=87) \text {, } \\
\text { typical adults }(n=47)\end{array}$ & $\begin{array}{l}\text { Parents differed from controls on social } \\
\text { anhedonia; Higher proportion of parents were } \\
\text { classed as alexithymic, compared with controls }\end{array}$ \\
\hline $\begin{array}{l}\text { Sucksmith et al. } \\
\text { (2013) [62] }\end{array}$ & Emotion recognition & $\begin{array}{l}314 \text { adults with ASD; } 297 \text { parents } \\
\text { with children with ASD; } 184 \\
\text { controls }\end{array}$ & $\begin{array}{l}\text { No difference between parents of a child with } \\
\text { ASD and controls at recognising the basic } \\
\text { emotions (after controlling for age and non- } \\
\text { verbal IQ) }\end{array}$ \\
\hline $\begin{array}{l}\text { Gizzonio et al. } \\
\text { (2014) [63] }\end{array}$ & Verbal IQ & $\begin{array}{l}32 \text { children with ASD, } 21 \text { siblings } \\
\text { of these children, }\end{array}$ & $\begin{array}{l}\text { No significant difference between Verbal } \\
\text { Intelligence Quotient and Performance } \\
\text { Intelligent Quotient scores between groups; }\end{array}$ \\
\hline
\end{tabular}




\begin{tabular}{|c|c|c|c|}
\hline Study & Characteristics & Participants & Main results \\
\hline & & $\begin{array}{l}43 \text { children with typical } \\
\text { development }\end{array}$ & $\begin{array}{l}\text { Not significant, a predominance of performance } \\
\text { over verbal abilities observed in siblings group }\end{array}$ \\
\hline $\begin{array}{l}\text { Kadak et al. (2014) } \\
\text { [64] }\end{array}$ & $\begin{array}{l}\text { Recognition of } \\
\text { emotion (face } \\
\text { expression) }\end{array}$ & $\begin{array}{l}36 \text { mothers and } 36 \text { fathers of } \\
\text { children with ASD; } 19 \text { mothers } \\
\text { and } 19 \text { fathers of typically } \\
\text { developing children }\end{array}$ & $\begin{array}{l}\text { Poorer recognition of emotional expressions in } \\
\text { ASD parents }\end{array}$ \\
\hline $\begin{array}{l}\text { Oerlemans et al. } \\
\text { (2014) [65] }\end{array}$ & $\begin{array}{l}\text { Recognition of facial } \\
\text { emotion and affective } \\
\text { prosody }\end{array}$ & $\begin{array}{l}90 \text { children with ASD ( } 43 \text { with } \\
\text { and } 47 \text { without ADHD), } 79 \text { ASD } \\
\text { unaffected siblings, } 139 \text { controls } \\
\text { aged 6-13 years }\end{array}$ & $\begin{array}{l}\text { The worse performance of unaffected siblings } \\
\text { than the controls and better than the ASD } \\
\text { probands in recognition of facial emotion and } \\
\text { affective prosody tasks }\end{array}$ \\
\hline
\end{tabular}

Table 1. Social communication and language characteristics in parents and siblings of individuals with ASD

As it is shown in Table 1, many authors have found social communication and language deficits in first-degree relatives of individuals with ASD. Both receptive and expressive language is affected [37]. Difficulties include, among others: pragmatic language deficits (e.g. [10, 12, 13, $32,36,44,46,55])$, verbal fluency [22], reading abilities [25, 35], delay of language development and problems in language developmental history [11,38, 43, 52], conversational skills [60] and syntax [41].

Some researchers, however, found no differences between first degree relatives of people with ASD and the comparison groups in the social communication and language (e.g. [33, 47, 51]). No such differences were found, among others, in the language development history [33], verbal fluency [51] and reading and spelling abilities [36, 55]. Similarly, there were no differences between parents or siblings of individuals with autism and control groups in terms of phonological processing $[38,51]$ and structural language $[53,57]$.

Findings on the development of verbal and non-verbal intellectual skills in first-degree relatives of people with autism are less consistent. Some comparisons have shown that firstdegree relatives of individuals with ASD had lower verbal IQ compared to control groups (e.g. [37]), while other studies found no such differences [36, 63]. Fombonne with colleagues [35] even reported slightly higher verbal IQ in relatives of individuals with autism than in relatives of people with Down syndrome.

Studies using self-reported measures to assess difficulties in communication experienced by parents of individuals with ASD have also failed to provide a clear picture. In the majority of those studies parents reported more severe difficulties in that area compared with adult controls (e.g. [8, 48, 56]). Scheeren and Stauder [50], however, found no differences when comparing parents of high-functioning individuals with autism and parents of typically developing children.

In a similar way several studies have indicated also that parents or siblings of children with ASD showed lower scores in recognize emotions tasks [34, 39, 42, 59, 61, 64, 65] than Down syndrome or typically developing children relatives. However, Sucksmith with colleagues 
[62], after controlling for age and non-verbal IQ, did not detect differences in recognizing the basic emotions between parents of children with ASD and controls.

It should be noted that in some studies in which differences between first-degree relatives of individuals with autism and controls were not significant it was possible to identify subgroups of participants demonstrating traits similar to those seen in individuals with ASD. Subgroups with BAP characteristics are significantly more numerous in the groups of parents or siblings of individuals with ASD than subgroups with similar problems in control groups. For instance, Landa with colleagues [32] stated that $42 \%$ of parents of children with ASD had some pragmatic language deficits, compared to $2 \%$ of control parents. Findings from research where it has been shown that among parents or siblings of people with autism there were the subgroups that manifested some difficulties in social communication and language, but it does not apply to these groups as a whole (e.g. $[43,45,49,54,60,66])$ may be particularly relevant to further research on genetic involvement in BAP. Schmidt with colleagues [51] showed impairments in phonological processing in parents of children with low functioning autism. In their study on emotion recognition, Adolphs with colleagues [49] found difficulties in parents identified as "socially aloof", while "nonaloof" parents were similar to controls. Folstein et al. [36] found that only those parents of individuals with autism who showed cognitive deficits associated with language in childhood performed worse than parents of individuals with Down syndrome in reading and writing tasks. By controlling for a variety of variables, including autism severity and developmental characteristics individuals with autism, as well as the number ASD cases in the extended family (e.g., taking into account the siblings of both parents of an individual with autism, as well as their children) we are likely to find out more about BAP.

Some empirical data suggest that families may differ in terms of genetic liability to autism. Losh et al. [13] compared three groups of individuals: 25 parents from multiple-incidence autism families, 40 parents from single-incidence autism families, and 30 parents from Down syndrome families. They found that autistic characteristics were most pronounced in parents from multiple-incidence autism families, less pronounced in single-incidence autism families, and weakest in parents of children with Down syndrome. In the majority of families with two children with autism, both parents demonstrated autistic characteristics; by contrast, in families with one child with autism the likelihood of both parents showing those characteristics was the same as for one parent or neither parent to have autistic traits. Gerdts and Bernier [66] showed that mothers, fathers, and siblings from multiplex ASD families were less expressive in their use of nonverbal communication compared to mothers, fathers and siblings from simplex families. Thus, it appears that research on multiple-incidence autism families can provide valuable information with respect to the hereditary mechanisms underlying autism. Schwichtenberg et al. [67] found that children from multiplex autism families had greater BAP traits than simplex siblings, and ASD multiplex infant siblings were more likely to develop ASD than ASD simplex and control. Findings from research on BAP in monozygotic and dizygotic twins are also interesting. It was shown [68] that concordance for BAP was much greater in $\mathrm{MZ}$ pairs than $\mathrm{DZ}$ pairs.

Recently there has been a surge in research on infants at high familial risk for ASD (see [69] for review). An estimated $10-20 \%$ of at high risk infant siblings may be affected by sub-clinical 
ASD symptoms or other developmental impairments [70]. These studies are not included in Table 1 because participants included children with ASD. Nevertheless, their findings with respect to social communication and language are relevant to the understanding of BAP. A number of those research projects have shown that some siblings of individuals with ASD demonstrate observable communication deficits already in the first three years of life and that these impairments can change over time. They include, among others, lower receptive language scores, delayed receptive and expressive language [15, 71-74], requesting behavior $[75,76]$, understanding words and phrases, gesture use, and social-communicative interactions with parents [77]. The important question is how early are those problems manifested. It was shown that at 6 months of age there were no statistically significant group differences in language development between high risk (HR, children having sibling with autism) and low risk (LR) infants (no autism history in family) [15, 78]. No differences in gaze following were found in children of 7 and 13 months between HR and LR groups [79]. Georgiades et al. [80] concluded that pragmatic language deficits were not relevant traits of BAP at 12 months. Obviously, this does not mean that HR children experience no deficits in language development at that age. Ozonoff with colleagues [78] found atypical language development in highrisk infants of 12 months of age. Differences in language between HR and LR infants of 24 months of age are found much more often [15, 73, 74]. Longitudinal studies are the most desirable as they offer insight into the dynamics and changes in the development of these children. While problems are overcome in some, in others they persist at later stages. As demonstrated by Gamliel et al. [71], expressive and receptive language deficits were still present in HR children at 54 months of age despite the resolution of some other developmental problems. Another important issue is to find out how many of 24-months old HR siblings demonstrating language difficulties are eventually diagnosed with ASD. Hudry et al. [81] found that reduced receptive vocabulary advantage in high risk infants at 14 months, maintained to 24 months only in the subgroups of ASD or other atypicality outcome. This suggests a close to typical development of other children in the HR group. The results of these sample studies on HR infants expose gaps in the knowledge on the issue.

\section{Conclusions}

Currently, it is difficult to identify universal, clear regularities relating to social communication and language deficits in parents or siblings of children with autism, but they have been found in some subgroups. A more complete knowledge in that area can contribute to a better understanding of autism. It can also provide hints for future research, by focusing attention on selected subgroups of parents and siblings.

There are many reasons for the variation in empirical results discussed in this section. Specific ones include methodological considerations such as sample size, research methods, enrolment criteria, as well as specifics of control groups (Cf. [19]).

It would be difficult to identify the components of BAP in terms of social communication and language based on currently available data. The best documented aspect of BAP appear to be 
pragmatic language deficits. Other characteristics analysed in the above studies as BAP components, such as delay of language development, difficulties in reading, spelling and writing, difficulties in structural language use or verbal fluency, remain controversial.

A number of studies on BAP focus on parents, and there are also many that analyse HR infants. In other studies on siblings, groups tend to be very heterogeneous, e.g. in terms of age. Longitudinal research on the development of social communication and language deficits in preschool and school age siblings are particularly necessary, especially that, as shown by Gamliel et al. [52], language may be a major area of difficulty for siblings of individuals with autism during the preschool years.

\section{Acknowledgements}

This paper was funded by the project of the National Science Center in Poland, \#UMO-2011/03/ B/HS6/03326.

\section{Author details}

Ewa Pisula and Karolina Ziegart-Sadowska*

*Address all correspondence to: ewa.pisula@psych.uw.edu.pl

Faculty of Psychology, University of Warsaw, Warsaw, Poland

\section{References}

[1] American Psychiatric Association. Diagnostic and Statistical Manual of Mental Disorders ( $5^{\text {th }}$ ed). Arlington: American Psychiatric Publishing; 2013.

[2] CDC. Prevalence of Autism Spectrum Disorder Among Children Aged 8 Years Autism and Developmental Disabilities Monitoring Network, 11 Sites, United States, 2010. Surveillance Summaries, March 28, 2014; 63(SS02): 1-21.

[3] Allen D A. Autistic spectrum disorders: clinical presentation in preschool children. Journal of Child Neurology 1988; 3(Suppl. S) 48-56.

[4] Wing L, Gould J. Severe impairment of social interaction and associated abnormalities in children: epidemiology and classification. Journal of Autism and Developmental Disorders 1979; 9(1) 11-29.

[5] Kanner L. Autistic disturbances of affective contact. Nervous Child 1943;2, 217-250. 
[6] Frith U., editor. Autism and Asperger Syndrome. Cambridge, Cambridge University Press; 1991.

[7] Bailey A, Palferman S, Heavey L, Le Couteur A. Autism: The phenotype in relatives. Journal of Autism and Developmental Disorders 1998;28(5) 369-392.

[8] Bishop DV, Maybery M, Maley A, Wong D, Hill W, Hallmayer J. Using self-report to identify the broad phenotype in parents of children with autistic spectrum disorders: a study using the Autism-Spectrum Quotient. Journal of Child Psychology and Psychiatry 2004;45(8) 1431-1436.

[9] Constantino J N, Lajonchere C, Lutz M, Gray T, Abbacchi A, McKenna K, Singh D, Todd RD. Autistic Social Impairment in Siblings of Children With Pervasive Developmental Disorders. The American Journal of Psychiatry 2006; 163(2) 294-296.

[10] Piven J, Palmer P, Landa R, Santangelo S, Jacobi D, Childress D. Personality and Language Characteristics in Parents From Multiple-Incidence Autism Families. American Journal of Medical Genetics (Neuropsychiatric Genetics) 1997;74(4) 398-411.

[11] Piven J, Palmer P, Jacobi D, Childress D, Arndt S. Broader autism phenotype: Evidence from a family history study of multiple-incidence autism families. American Journal of Psychiatry 1997;154(2) 185-190.

[12] Bolton P, Macdonald H, Pickles A, Rios P, Goode S, Crowson M, Bailey A, Rutter M. A case-control family history study of autism. Journal of Child Psychology and Psychiatry 1994;35(5) 877-900.

[13] Losh M, Childress D, Lam K, Piven J. Defining Key Features of the Broad Autism Phenotype. American Journal of Medicine Genetics 2008;147B(4) 424-433.

[14] Sucksmith E, Roth I, Hoekstra R A. Autistic traits below the clinical threshold: re-examining the broader autism phenotype in the 21st century. Neuropsychology Review 2011;21(4), 360-389.

[15] Landa R, Garrett Mayer E. Development in infants with autism spectrum disorders: A prospective study. Journal of Child Psychology and Psychiatry 2006;47(6) 629-638.

[16] Boelte S, Poustka F. The broader cognitive phenotype of autism in parents: how specific is the tendency for local processing and executive disfunction? Journal of Child Psychology \& Psychiatry 2006;47(6) 639-645.

[17] Kano Y, Ohta M, Nagai Y, Pauls DL, Leckman JF. Obsessive-compulsive symptoms in parents of Tourette syndrome probands and autism spectrum disorder probands. Psychiatry and Clinical Neurosciences 2004;58(4) 348-352.

[18] Ghaziuddin M. A family history study of Asperger syndrome. Journal of Autism and Developmental Disorders 2005;35(2) 177-182.

[19] Yirmiya N, Shaked M. Psychiatric disorders in parents of children with autism: a meta-analysis. Journal of Child Psychology and Psychiatry 2005;46(1) 69-83. 
[20] Briskman J, Happé F, Frith U. Exploring the cognitive phenotype of autism: weak "central coherence" in parents and siblings of children with autism: II. Real-life skills and preferences. Journal of Child Psychology and Psychiatry 2001;42(3) 309-316.

[21] Happé F, Briskman J, Frith U. Exploring the cognitive phenotype of autism: Weak 'central coherence' in parents and siblings of children with autism: I. Experimental tests. Journal of Child Psychology and Psychiatry 2001,42(3) 299-307.

[22] Hughes C, Plumet MH, Leboyer M. Towards a Cognitive Phenotype for Autism: Increased Prevalence of Executive Dysfunction and Superior Spatial Span amongst Siblings of Children with Autism. Journal of Child Psychology \& Psychiatry 1999;40(5) 705-718.

[23] Losh M, Esserman D, Piven J. Rapid automatized naming as an index of genetic liability to autism. Journal of Neurodevelopmental Disorders 2010;2(2) 109-116.

[24] Nyden A, Hagberg B, Gousse V, Rastam M. A cognitive endophenotype of autism in families with multiple incidence. Research in Autism Spectrum Disorders 2011;5(1) 191-200.

[25] Piven J, Palmer P. Cognitive deficits in parents from multiple-incidence autism families. Journal of Child Psychology and Psychiatry 1997;38(8) 1011-1021.

[26] Wong D, Maybery M, Bishop DVM, Maley A, Hallmayer J. Profiles of executive function in parents and siblings of individuals with autism spectrum disorders. Genes, Brain and Behavior 2006;5(8) 561-576.

[27] Cruz LP, Camargos-Júnior W, Lopes Rocha F. The broad autism phenotype in parents of individuals with autism: a systematic review of the literature. Trends in Psychiatry and Psychotherapy 2013;35(4) 252-263.

[28] Gerdts J, Bernier R. The Broader Autism Phenotype and Its Implications on the Etiology and Treatment of Autism Spectrum Disorders. Autism Research and Treatment 2011, Article ID 545901, 19 pages.

[29] World Health Organization. Manual of the International Statistical Classification of the Diseases, and Related Health Problems (10 ${ }^{\text {th }}$ ed, vol.1). Genewa: WHO; 2002.

[30] Dawson G, Webb S, Schellenberg GD, Dager S, Friedman S, Aylward E, Richards T. Defining the broader phenotype of autism: genetic, brain, and behavioral perspectives. Development and Psychopathology 2002;14(3) 581-611.

[31] Ingersoll B. Broader autism phenotype and nonverbal sensitivity: Evidence for an association in the general population. Journal of Autism and Developmental Disorders 2010;40(5) 590-598.

[32] Landa R, Piven J, Wzorek M, Gayle J, Chase G, Folstein S. Social language use in parents of autistic individuals. Psychological Medicine 1992;22(1) 245-254.

[33] Szatmari P, Jones MB, Tuff L, Bartolucci G, Fisman S, Mahoney W. Lack of cognitive impairment in first-degree relatives of children with pervasive developmental disor- 
ders. Journal of the American Academy of Child and Adolescent Psychiatry 1993;32(6) 1264-1273.

[34] Baron-Cohen S, Hammer J. Parents of children with Asperger syndrome: What is the cognitive phenotype? Journal of Cognitive Neuroscience 1997;9(4) 548-554.

[35] Fombonne E, Bolton P, Prior J, Jordan H, Rutter M. A family study of autism: cognitive patterns and levels in parents and siblings. Journal of Child Psychology and Psychiatry and Allied Disciplines 1997;38(6) 667-683.

[36] Folstein SE, Santangelo SL, Gilman SE, Piven J, Landa R, Lainhart J, Hein J, Wzorek M. Predictors of cognitive test patterns in autism families. Journal of Child Psychology and Psychiatry 1999;40(7) 1117-1128.

[37] Pilowsky T, Yirmiya N, Shalev RS, Gross-Tsur V. Language abilities of siblings of children with autism. Journal of Child Psychology and Psychiatry 2003;44(6) 914-925.

[38] Bishop DV, Maybery M, Wong D, Maley A, Hill W, Hallmayer J. Are phonological processing deficits part of the broad autism phenotype? American Journal of Medical Genetics Part B: Neuropsychiatric Genetics 2004; 128B(1) 54-60.

[39] Dorris L, Espie CAE, Knott F, Salt J. Mind reading difficulties in the siblings of people with Asperger's syndrome: Evidence for a genetic influence in the abnormal development of a specific cognitive domain. Journal of Child Psychology and Psychiatry 2004;45(2) 412-418.

[40] Hill E, Berthoz S, Frith U. Brief report: cognitive processing of own emotions in individuals with autistic spectrum disorder and in their relatives. Journal of Autism and Developmental Disorders 2004;34(2) 229-235.

[41] Bishop DV, Maybery M, Wong D, Maley A, Hallmayer J. Characteristics of the broader phenotype in autism: a study of siblings using the children's communication checklist-2. American Journal of Medical Genetics Part B 2006;141B(2) 117-122.

[42] Palermo MT, Pasqualetti P, Barbati G, Intelligente F. Rossini PM. Recognition of schematic facial displays of emotion in parents of children with autism. Autism 2006;10(4) 353-364.

[43] Chuthapisith J, Ruangdaraganon N, Sombuntham T, Roongpraiwan R. Language development among the siblings of children with autistic spectrum disorder. Autism 2007;11(2) 149-160.

[44] Di Michelle V, Mazza M, Cerbo R, Roncone R, Casacchia M. Deficits in pragmatic conversation as manifestation of genetic liability in autism. Clinical Neuropsychiatry 2007;4(4) 144-151.

[45] Losh M, Piven J. Social-cognition and the broad autism phenotype: identifying genetically meaningful phenotypes. Journal of Child Psychology and Psychiatry 2007;48(1) $105-112$. 
[46] Ruser TF, Arin D, Dowd M, Putnam S, Winklosky B, Rosen-Sheidley B, Piven J, Tomblin B, Tager-Flusberg H, Folstein S. Communicative competence in parents of children with autism and parents of children with specific language impairment. Journal of Autism and Developmental Disorders 2007;37(7) 1323-1336.

[47] Pilowsky T, Yirmiya N, Gross-Tsur V, Shalev RS. Neuropsychological Functioning of Siblings of Children with Autism, Siblings of Children with Developmental language Delay, and Siblings of Children with Mental Retardation of Unknown Genetic Etiology. Journal of Autism and Developmental Disorders 2007;37(3) 537-552.

[48] Whitehouse AJ, Barry JG, Bishop DV. The broader language phenotype of autism: a comparison with specific language impairment. Journal of Child Psychology and Psychiatry 2007;48(8) 822-830.

[49] Adolphs R, Spezio, M L, Parlier M, Piven J. Distinct face-processing strategies in parents of autistic children. Current Biology 2008;18(14) 1090-1093.

[50] Scheeren AM, Stauder JE. Broader autism phenotype in parents of autistic children: reality or myth? Journal of Autism and Developmental Disorders 2008;38(2) 276-287.

[51] Schmidt GL, Kimel LK, Winterrowd E, Pennington BF, Hepburn SL, Rojas DC. Impairments in phonological processing and nonverbal intellectual function in parents of children with autism. Journal of Clinical and Experimental Neuropsychology 2008;30(5) 557-567.

[52] Gamliel I, Yirmiya N, Jaffe DH, Manor O, Sigman M. Developmental Trajectories in Siblings of Children with Autism: Cognition and Language from 4 Months to 7 Years. Journal of Autism and Developmental Disorders 2009;39(8) 1131-1144.

[53] Lindgren KA, Folstein SE, Tomblin JB, Tager-Flusberg H. Language and reading abilities of children with autism spectrum disorders and specific language impairment and their first-degree relatives. Autism Research 2009;2(1) 22-38.

[54] Losh M, Adolphs R, Poe MD, Couture S, Penn D, Baranek GT, Piven J. Neuropsychological profile of autism and the broad autism phenotype. Archives of General Psychiatry 2009;66(5) 518-526.

[55] Ben-Yizhak N, Yirmiya N, Seidman I, Alon R, Lord C, Sigman M. Pragmatic Language and School Related Linguistic Abilities in Siblings of Children with Autism. Journal of Autism and Developmental Disorders 2011;41(6) 750-760.

[56] Wheelwright S, Auyeung B, Allison C, Baron-Cohen S. Defining the broader, medium and narrow autism phenotype among parents using the Autism Spectrum Quotient (AQ). Molecular Autism 2010;1(10) 2-9.

[57] Whitehouse AJ, Coon H, Miller J, Salisbury B, Bishop DV. Narrowing the broader autism phenotype: a study using the Communication Checklist - Adult Version (CCA). Autism 2010;14, 559-574. 
[58] Levy Y, Bar-Yuda C. Language performance in siblings of nonverbal children with autism. Autism 2011;15(3) 341-354.

[59] Neves MC, Tremeau F, Nicolato R, Lauar H, Romano-Silva MA, Correa H. Facial emotion recognition deficits in relatives of children with autism are not associated with 5HTTLPR. The Revista Brasileira de Psiquiatria 2011;33(3) 261-267.

[60] Bernier R, Gerdts J, Munson J, Dawson G, Estes A. Evidence for broader autism phenotype characteristics in parents from multiple-incidence autism families. Autism Research 2012;5(1) 13-20.

[61] Berthoz S, Lalanne Ch, Crane L, Hill E L. Investigating emotional impairments in adults with autism spectrum disorders and the broader autism phenotype. Psychiatry Research 2013;208(3) 257-264.

[62] Sucksmith E, Allison C, Baron-Cohen S, Chakrabarti B, Hoekstra RA. Empathy and emotion recognition in people with autism, first-degree relatives, and controls. Neuropsychologia 2013;51(1) 98-105.

[63] Gizzonio V, Avanzini P, Fabbri-Destro M, Campi Ch, Rizzolatti G. Cognitive abilities in siblings of children with autism spectrum disorders. Experimental Brain Research 2014;232(7) 2381-2390.

[64] Kadak MT, Demirel ÖF, Yavuz M, Demir T. Recognition of emotional facial expressions and broad autism phenotype in parents of children diagnosed with autistic spectrum disorder. Comprehensive Psychiatry 2014;55(5) 1146-1151.

[65] Oerlemans AM, van der Meer JM, van Steijn DJ, de Ruiter SW, de Bruijn YG, de Sonneville LM, Buitelaar JK, Rommelse NN. Recognition of facial emotion and affective prosody in children with ASD (+ADHD) and their unaffected siblings. European Child and Adolescent Psychiatry 2014;23(5) 257-271.

[66] Gerdts JA, Bernier R, Dawson G, Estes A. The Broader Autism Phenotype in Simplex and Multiplex Families. Journal ofAutism and Developmental Disorders 2013;43, 1597-1605.

[67] Schwichtenberg AJ, Young GS, Sigman M, Hutman T, Ozonoff S. Can family affectedness inform infant sibling outcomes of autism spectrum disorders? Journal of Child Psychology and Psychiatry 2010;51(9) 1021-1030.

[68] Le Couteur A, Bailey A, Goode S, Pickles A, Robertson S, Gottesman I, Rutter MA. Broader phenotype of autism: the clinical spectrum in twins. Journal of Child Psychology and Psychiatry 1996;37(7) 785-801.

[69] Jones EJH, Gliga T, Bedford R, Charman T, Johnson MH. Developmental pathways to autism: A review of prospective studies of infants at risk. Neuroscience and Biobehavioral Reviews 2014;39(100) 1-33.

[70] Messinger D, Young GS, Ozonoff S, Dobkins K, Carter A, Zwaigenbaum L, Landa RJ, Charman T, Stone WL, Constantino JN, Hutman T, Carver LJ, Bryson S, Iverson JM, 
Strauss MS, Rogers SJ, Sigman M. Beyond autism: a baby siblings research consortium study of high-risk children at three years of age. Journal of the American Academy of Child and Adolescent Psychiatry 2013;52(3) 300-308.

[71] Gamliel I, Yirmiya N, Sigman M. The development of young siblings of children with autism from 4 to 54 months. Journal of Autism and Developmental Disorders 2007;37(1) 171-183.

[72] Toth K, Dawson G, Meltzoff AN, Greenson J, Fein D. Early Social, Imitation, Play, and Language Abilities of Young Non - Autistic Siblings of Children with Autism. Journal of Autism and Developmental Disorders 2007;37(1) 145-157.

[73] Yirmiya N, Gamliel I, Pilowsky T, Feldman R, Baron-Cohen S, Sigman M. The development of siblings of children with autism at 4 and 14 months: social engagement, communication, and cognition. Journal of Child Psychology and Psychiatry 2006;47(5) 511-523.

[74] Zwaigenbaum L, Bryson S, Rogers T, Roberts W, Brian J, Szatmari P. Behavioral manifestations of autism in the first year of life. International Journal of Developmental Neuroscience 2005;23(2-3) 143-152.

[75] Cassel TD, Messinger DS, Ibanez LV, Haltigan JD, Acosta SI, Buchman AC. Early Social and Emotional Communication in the Infant Siblings of Children with Autism Spectrum Disorders: An Examination of the Broad Phenotype. Journal of Autism and Developmental Disorders 2007;37(1) 122-132.

[76] Goldberg WA, Jarvis KL, Osann K, Laulhere TM, Straub C, Thomas E, Filipek P, Spence MA. Brief report: Early social communication behaviors in the younger siblings of children with autism. Journal of Autism and Developmental Disorders 2005;35(5) 657-664.

[77] Stone WL, McMahon CR, Yoder PJ, Walden TA. Early social-communicative and cognitive development of younger siblings of children with autism spectrum disorders. Archives of Pediatrics and Adolescent Medicine 2007;161, 384-390.

[78] Ozonoff S, Young GS, Belding A, Hill M, Hill A, Hutman T, Johnson S, Miller M, Rogers SJ, Schwichtenberg AJ, Steinfeld M, Iosif AM. The broader autism phenotype in infancy: when does it emerge? Journal of the American Academy of Child and Adolescent Psychiatry 2014;53(4) 398-407.

[79] Bedford R, Elsabbagh M, Gliga T, Pickles A, Senju A, Charman T, Johnson M H, the BASIS team. Precursors to Social and Communication Difficulties in Infants At-Risk for Autism: Gaze Following and Attentional Engagement. Journal of Autism and Developmental Disorders 2012;42(10) 2208-2218.

[80] Georgiades S, Szatmari P, Zwaigenbaum L, Bryson S, Brian J, Roberts W, Smith I, Vaillancourt T, Roncadin C, Garon N. A prospective study of autistic-like traits in 
unaffected siblings of probands with autism spectrum disorder. JAMA Psychiatry 2013;70(1) 42-48.

[81] Hudry K, Chandler S, Bedford R, Pasco G, Gliga T, Elsabbagh M, Johnson MH, Charman T. Early language profiles in infants at high-risk for autism spectrum disorders. Journal of Autism and Developmental Disorders 2014;44(1) 154-167. 